\title{
Identification of Leaf Rust Resistance Genes in Wheat Cultivars Produced in Kazakhstan
}

\author{
A. Kokhmetova ${ }^{1 *}$, A. Madenova ${ }^{1,2}$, G. Kampitova $^{2}$, R. Urazaliev $^{3}$, M. Yessimbekova $^{3}$, \\ A. Morgounov ${ }^{4}$ and L. Purnhauser ${ }^{5}$ \\ ${ }^{1}$ Institute of Plant Biology and Biotechnology, 45 Timiryazev Street, 050040, Almaty, Kazakhstan \\ ${ }^{2}$ Kazakh National Agricultural University, 8 Abay Av., Almaty, Kazakhstan \\ ${ }^{3}$ Kazakh Research Institute of Farming, Almalybak, Almaty reg., Kazakhstan \\ ${ }^{4}$ International Maize and Wheat Improvement Center (CIMMYT), Emek, Ankara, Turkey \\ ${ }^{5}$ Cereal Research Non-Profit Ltd. Co., H-6726, Alsó kikötő sor 9, Szeged, Hungary
}

\author{
(Received 24 April 2015; Accepted 20 October 2015; \\ Communicated by J. Kolmer)
}

Leaf rust, caused by Puccinia recondita f. sp. tritici, is one of the major diseases of wheat in Kazakhstan. To effectively use leaf rust resistance genes $(L r)$, it is important for breeders to know the resistance genotype in current cultivars. In this study, 30 winter wheat entries grown and/or produced in Kazakhstan were investigated using molecular markers to determine the presence and absence of eight important $L r$ genes. Molecular screening of these genotypes showed contrasting differences in the frequencies of these genes. Among the 30 entries, 17 carried leaf rust resistance gene $\operatorname{Lr} 1$, six had $\operatorname{Lr} 26$ and $L r 34$, and $L r 10$ and $L r 37$ were found in three cultivars. Two single cultivars separately carried $\operatorname{Lr} 19$ and $\operatorname{Lr} 68$, while $L r 9$ was not detected in any genotypes in this study. Field evaluation demonstrated that two of the most frequent two genes ( $L r 1$ and $L r 26$ ) to be ineffective. While $L r 34$ provided some protection, the remaining effective $L r$ genes were found only in few genotypes: $L r 37$ occurred in Kazakh genotypes L-1090 and Krasnovodapadskaya 210 and in the US cultivar Madsen; Lr19 and Lr68 were likely present only in Russian and Kazakh cultivars, Pallada and Yegemen, respectively. The highest resistance over three years of leaf rust testing was found in Kazakh cultivars, Karasay, Krasnovodapadskaya 210, L-1090, Arap and Yegmen, foreign cultivars Madsen, Pallada and the control Parula (Lr68). Data may assist breeders to incorporate effective $L r$ genes into new cultivars.

Keywords: ACI, efficiency, frequency, $L r$ genes, winter wheat, molecular markers, Triticum aestivum

\section{Introduction}

The region of Central Asia is one of the world's most important producers of wheat, encompassing a production are of more than 15 million ha. Leaf rust, caused by Puccinia recondita f. sp. tritici (Prt) has caused serious damage to both yield and grain quality in certain seasons. In the period between 2001 and 2009 in North Kazakhstan, leaf rust epi-

\footnotetext{
*Corresponding author; E-mail: gen_kalma@mail.ru
} 
demics occurred five times (2002, 2003, 2005, 2007 and 2009) and the yield loss reached $20-30 \%$ in the most susceptible cultivars (Koishybayev et al. 2010; Kokhmetova et al. 2014). The use of genetically resistant cultivars is considered to be the most effective, economic and environmentally safe method for disease control.

Currently, more than 70 leaf rust resistance genes have been described (McIntosh et al. 2010) although many of these genes have become ineffective with the occurrence of new virulent races of the pathogen that can overcome resistance. Based on recent evaluations in Kazakhstan, genes $\operatorname{Lr} 9, \operatorname{Lr} 10, \operatorname{Lr} 1$ 9, Lr34, Lr37 and Lr68 were still effective and Lr1 was not effective (Koishybayev et al. 2010; Rsaliev et al. 2011). Some of the $L r$ genes are closely linked to other resistance genes, e.g. $\mathrm{Lr19} / \mathrm{Sr} 25$; $\mathrm{Lr} 26 / \mathrm{Yr}$ 9/Sr31/Pm8, $\mathrm{Lr37} / \mathrm{Yr} 17 /$ $\mathrm{Sr} 38$ and $\mathrm{Lr} 34 / \mathrm{Yr} 18 / \mathrm{Pm} 38$, that are still effective or are of great interest as a donors of valuable agronomic traits.

The conventional means of transferring one or more resistance genes has been used in field and greenhouse screening of wheats with different races of Prt. This a very laborious process and is subject to the variability of seasonal conditions. Molecular markers can be efficiently used to identify resistance genes in cultivars, to combine them in a suitable background, and to assist in selecting lines with appropriate gene combinations. Molecular markers closely or perfectly linked to $L r$ genes were identified in many cases, such as Lr1 (Feuillet et al. 1995); Lr9 (Schachermayr et al. 1994); Lr10 (Schachermayr et al. 1997); Lr19 (Prins et al. 2001); Lr26 (Weng et al. 2007); Lr34 (Lagudah et al. 2006); Lr37 (Helguera et al. 2003), and the Lr68 (Herrera-Foessel et al. 2012).

To develop new wheat cultivars resistant to Prt, it is very important to have information about $L r$ genes present in current varieties and advanced lines. The goal of this study was to use molecular markers to determine the presence/absence and frequency of eight selected $\operatorname{Lr}$ genes (Lr1, Lr9, Lr10, Lr19, Lr26, Lr34, Lr37 and Lr68) in winter wheat cultivars widely used in wheat production in Kazakhstan and in advanced lines developed in this country.

\section{Materials and Methods}

Thirty winter wheat entries were selected from those produced in Kazakhstan and Central Asian countries. These included 18 wheat cultivars (registered between 1976 and 2011), four cultivar candidates from Kazakhstan, one advanced high-yielding line from CIMMYT (Mexico), three cultivars from Russia, two from Uzbekistan, one from Kyrgyzstan, one from USA and one from Mexico. The highly susceptible control cultivar Morocco and the resistant check Parula (Mexico) carrying Lr68 as well as the near isogenic lines (NILs) of cv. Thatcher: NIL Lr1 (RL6003), NIL Lr9 (RL6010), NIL Lr10 (RL6004), NIL Lr19 (RL6040), NIL Lr26 (RL6078), NIL Lr34 (RL6058) and NIL Lr37 (RL6081) were also used in both tests.

Field observations were conducted at the experimental station of Kazakh Research Institute of Farming (KazRIF), Almalybak, Almaty region over three years (2012-2014). Annual rainfall ranged from 332 to $644 \mathrm{~mm}$ during the three years. Experiments were sown in $1 \mathrm{~m}^{2}$ plots in the middle of September in each three experimental years. 
Field plots were inoculated with mixed races of Prt obtained from 80 to 100 random infected leaf samples collected from main winter wheat growing areas of Kazakhstan. Sampling of spores, their storage, and reproduction were carried out according to methods of Roelfs et al. (1992). Inoculum was multiplied in the greenhouse on cultivar Morocco and the collected urediniospores were inoculated by a spore: talc mixture $(1: 100$, $20 \mathrm{mg} / \mathrm{m}^{2}$ ) applied in the heading stage in spring.

Infection type and severity data were recorded in late May and early June when the plots were at boot and milk stages, respectively. The time of second evaluation was also determined when rust severity on the susceptible control Morocco reached $60-80 \%$. Scoring of leaf rust symptoms was performed according to the method developed at the CIMMYT (Roelfs et al. 1992). The five infection types (IT) were: 0 -immune; $\mathrm{R}$ - resistant; MR - moderately resistant; MS - moderately susceptible; and S - susceptible. Partial resistance in the field was evaluated at boot and milk stages, respectively, using the modified Cobb scale (Peterson et al., 1948), as well as the coefficients of infection (CI) and the average coefficient of infection (ACI). CI was calculated by multiplying the severity values by the constant values for infection types, based on: $\mathrm{R}=0.2, \mathrm{MR}=0.4, \mathrm{MS}=0.8$ and $\mathrm{S}=1.0$ (Stubbs et al. 1986).

Genomic DNA was isolated at two-leaf seedling stage for each genotype using the CTAB method (Riede and Anderson 1996). Primers and annealing temperature conditions of polymerase chain reaction (PCR) were carried out as described for each $\mathrm{Lr}$ gene in the references (Table 1). PCR reactions were performed in a Bio-Rad T100 TM Thermal Cycler. For each PCR reaction, the $15 \mu 1$ reaction volume contained $30 \mathrm{ng}$ of template DNA; 1X PCR buffer, $0.75 \mathrm{U}$ of Taq DNA polymerase (ZAO Sileks, Russia), $1.5 \mathrm{mM}$ of $\mathrm{MgCl}_{2}, 0.2 \mathrm{mM}$ each of dCTP, dGTP, dTTP, and dATP (ZAO Sileks, Russia) and $0.2 \mu \mathrm{M}$ of each primer synthesized by Sigma-Aldrich. Amplification was performed using the following parameters: initial denaturation $\left(94^{\circ} \mathrm{C}\right.$ for $\left.5 \mathrm{~min}\right), 45$ cycles (94 ${ }^{\circ} \mathrm{C}$ for $1 \mathrm{~min}, 50-65{ }^{\circ} \mathrm{C}$ for $1 \mathrm{~min}, 72{ }^{\circ} \mathrm{C}$ for $2 \mathrm{~min}$ ), and final extension $\left(72{ }^{\circ} \mathrm{C}\right.$ for $7 \mathrm{~min}$ ) with some modifications to optimize certain primer combinations. For the sepa-

Table 1. Markers and primers used to identify the presence of $L r$ genes in wheat cultivars produced or used in Kazakhstan

\begin{tabular}{|c|l|c|c|l|}
\hline Gene & \multicolumn{1}{|c|}{ Markers } & $\begin{array}{c}\text { Distance } \\
\text { of marker from } \\
\text { gene }(\mathrm{cM})\end{array}$ & $\begin{array}{c}\text { Tm of primers } \\
\left({ }^{\circ} \mathrm{C}\right)\end{array}$ & \multicolumn{1}{|c|}{ Reference } \\
\hline Lr1 & pTAG 621-3 and -5 & 0.0 & 55 & Feuillet et al. (1995) \\
\hline Lr9 & J13/1 and J13/2 & 8.0 & 62 & Schachermayr et al. (1994) \\
\hline Lr10 & F1.2245 and Lr10-6/r2 & 0.0 & 57 & Schachermayr et al. (1997) \\
\hline Lr19 & Gb-F and -R & 0.0 & 60 & Prins et al. (2001) \\
\hline Lr26 & SCM9-F and -R & 0.0 & 55 & Weng et al. (2007) \\
\hline Lr34 & csLV34-F and -R & 0.4 & 56 & Lagudah et al. (2006) \\
\hline Lr37 & VENTRIUP/LN2-F and -R & 0.0 & 65 & Helguera et al. (2003) \\
\hline Lr68 & csGS-F and -R & 1.2 & 60 & Herrera-Foessel et al. (2012) \\
\hline
\end{tabular}


ration of amplified DNA fragments, electrophoresis was conducted in 2\% agarose gel in TBE buffer (45 mM Tris borate, $1 \mathrm{mM}$ EDTA, $\mathrm{pH}$ 8) and bands were visualized on UV transluminator.

\section{Results}

Closely linked markers of all eight investigated $L r$ genes were individually identified in each corresponding NILs as well as in cv. Parula (Lr68), which supported the methods used in this study (Table 2). The expected marker fragment associated with Lrl was found in 12 of the 22 Kazakh entries, and 5 of the 9 foreign ones. The marker for $\operatorname{Lr} 9$ was not found in any genotypes in this study. The marker linked to Lr10 was found only in two Kazakh genotypes (Yegmen and Dinara), and in cv. Adyr from Kyrgyzstan. The marker fragment specific to Lr19 was found only in cv. Pallada from Russia. The 1BL.RS translocation carrying Lr26 was present in three Kazakh cultivars (Karasay, Taza and Sapaly) and in three foreign stocks (Kupava from Russia, Ulugbek 600 from Uzbekistan and Adyr from Kyrgyzstan). The marker linked to Lr34 was detected in five of the Kazakh cultivars (Almaly, Nureke, Karasay, Mereke 70 and L286) and in foreign cultivars (Bezostaya 1 from Russia) and the Lr68 control Parula (Mexico). The marker linked to Lr37 was found in two Kazakh stocks (Krasnovodopadskaya 210 and L-1090), and also in the foreign cv. Madsen (USA). The marker closely linked to Lr68 was found only in one Kazakh genotype, cv. Yegmen.

From all entries investigated three Kazakh wheats, a Mexican stock and also the susceptible cultivar Morocco failed to show evidence of any of the eight $\mathrm{Lr}$ markers tested. The markers detected three gene combinations in Kazakh cv. Karasay ( $\operatorname{lr} 1, \operatorname{Lr} 26$ and Lr34) and cv. Adyr from Kyrgyzstan ( $L r 1, L r 10$ and Lr26).

Under artificial infection conditions the three year average ACI values for the entries deriving from data of the total 9 observations for each entries ( 3 years $\times 3$ replicates) ranged from 5.8 and 18.6 for the $1^{\text {st }}$ (boot stage) and the $2^{\text {nd }}$ (milk stage) observations, respectively (Table 2). The highest ACI values for test entries were 12.0 and 29.3, respectively (for cv. Morocco these values reached 13.3 and 60.0). The two most resistant cultivars ( 0.7 and 1.7 average $\mathrm{ACI}$ values for the $2^{\text {nd }}$ observations during the 3 years) were Parula (the control cultivar from Mexico) and Madsen (USA) carrying Lr34/Lr68 and Lr37, respectively. Amongst the next six most resistant cultivars (ACI values: 4.7-8.7) five originated from Kazakhstan. Two of them carried the Lr37 (Krasnovodapadskaya 210 and L-1090) and one $\operatorname{Lr} 68$ (Yegemen). The two other Kazakh cultivars, Karasay and Arap, contained $L r 1+L r 26+L r 34$ or $L r 1$, respectively. Arap is interesting because as later it will be shown that $L r 1$ was an ineffective gene for leaf rust (Tables 2 and 3). One foreign cultivar, Pallada (Russia), which carried Lr19, also belonged to this group. Among the nine most susceptible genotypes three did not carry any of the eight $L r$ genes, and the rest carried only the $L r 1$ and/or $L r 26$.

Cultivars carrying $\operatorname{Lr} 19$, $\operatorname{Lr} 37$ or $\operatorname{Lr} 68$ resistance genes all provided high levels of resistance against leaf rust (Table 2). Statistical analysis of ACI data of groups of cultivars with or without these genes also supported these observations. The average ACI data ( $2^{\text {nd }}$ observations) of the three $\operatorname{Lr} 37$ carriers (5.3) (excluding NIL Lr37 control) was signifi- 


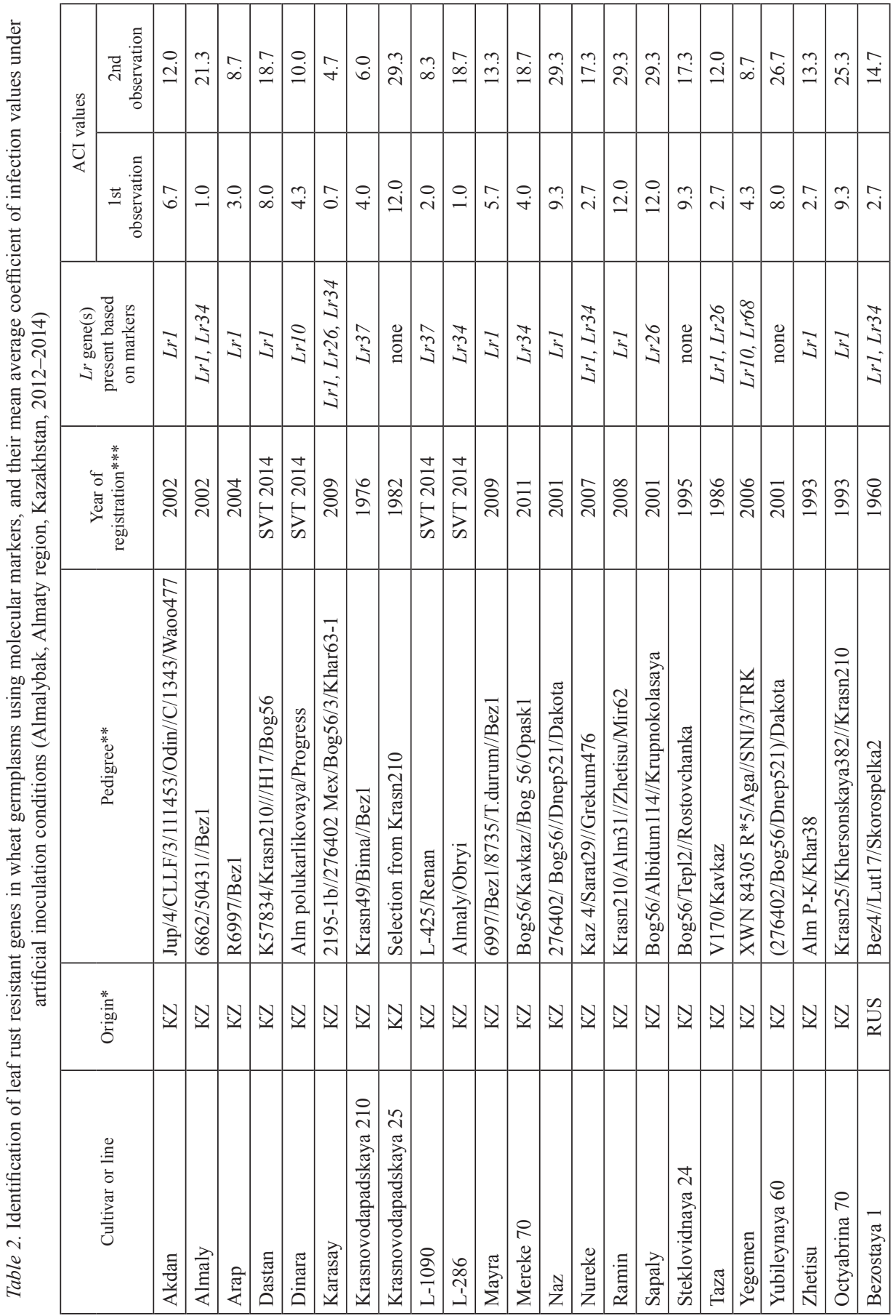




\begin{tabular}{|c|c|c|c|c|c|c|c|c|c|c|c|c|c|c|c|c|c|c|c|}
\hline 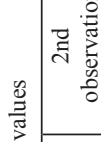 & $\begin{array}{l}- \\
\infty\end{array}$ & $\underset{\infty}{\infty}$ & $\begin{array}{l}0 \\
i \\
\end{array}$ & $\overrightarrow{\dot{d}}$ & 导 & $\Xi$ & $\stackrel{\circ}{\stackrel{+}{v}}$ & & $\begin{array}{l}0 \\
\dot{8} \\
0\end{array}$ & $\ddot{0}$ & $\stackrel{n}{\hat{\lambda}}$ & 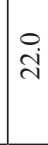 & 导 & $\stackrel{\sim}{ \pm}$ & $\mid \begin{array}{l}0 \\
i \\
m\end{array}$ & $\hat{\grave{d}}$ & $\stackrel{0}{\circ}$ & $\begin{array}{l}0 \\
\infty \\
\infty\end{array}$ & $\stackrel{?}{r}$ \\
\hline 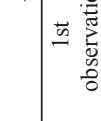 & $\stackrel{m}{m}$ & $\stackrel{0}{-}$ & $\stackrel{\odot}{+}$ & $\stackrel{m}{a}$ & $\stackrel{m}{a}$ & $\ddot{0}$ & in & & $\begin{array}{l}m \\
m \\
m\end{array}$ & $\stackrel{m}{0}$ & $\ddot{0}$ & $\stackrel{\circ}{\dot{r}}$ & $\stackrel{n}{a}$ & $\begin{array}{l}0 \\
\dot{m}\end{array}$ & $\ddot{0}$ & $\underset{i}{i}$ & $\stackrel{\circ}{+}$ & $\stackrel{\infty}{i}$ & $\stackrel{\sim}{\sim}$ \\
\hline 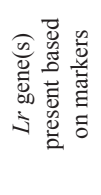 & 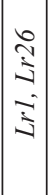 & 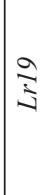 & $\Xi$ & $\mid \begin{array}{l}0 \\
\stackrel{2}{1} \\
\vdots \\
-1 \\
\vdots \\
\vdots\end{array}$ & 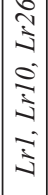 & $\begin{array}{c}n \\
\vdots \\
\vdots\end{array}$ & $\begin{array}{l}\stackrel{\Xi}{\Xi} \\
\Xi\end{array}$ & & $\mid \begin{array}{l}\mathscr{\Xi} \\
\Xi\end{array}$ & $\begin{array}{l}\infty \\
\stackrel{0}{1} \\
\frac{1}{+5} \\
0 \\
\vdots\end{array}$ & $\exists$ & $\stackrel{a}{\ddagger}$ & $\stackrel{2}{\sharp}$ & 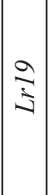 & $\begin{array}{l}0 \\
\stackrel{1}{\Xi} \\
\end{array}$ & $\begin{array}{l}0 \\
0 \\
\vdots\end{array}$ & $\begin{array}{c}\hat{n} \\
\vdots\end{array}$ & & \\
\hline 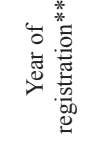 & ळे & 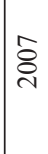 & & $\vec{\delta}$ & $\overrightarrow{8}$ & $\mid \begin{array}{l}\infty \\
\infty \\
\varrho\end{array}$ & 1 & & 1 & 1 & 1 & 1 & 1 & 1 & 1 & 1 & 1 & & \\
\hline 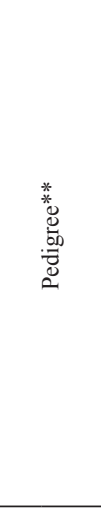 & 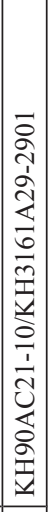 & 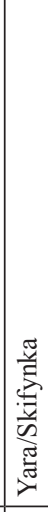 & 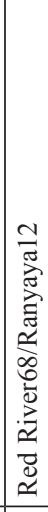 & & 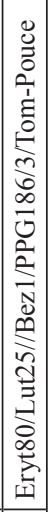 & 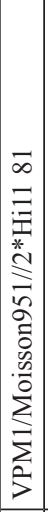 & 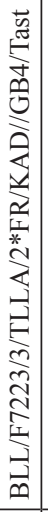 & & & 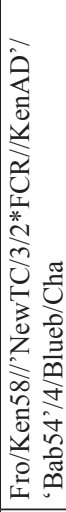 & 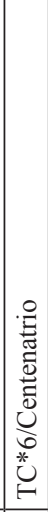 & 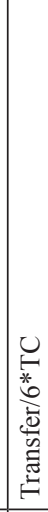 & 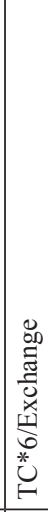 & 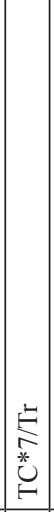 & 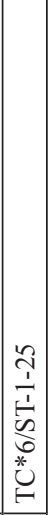 & 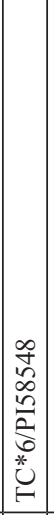 & 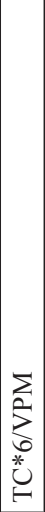 & & \\
\hline$\stackrel{*}{*} \stackrel{*}{\stackrel{5}{5}}$ & $\stackrel{\Omega}{\Omega}$ & $\stackrel{\Omega}{\Omega}$ & $\stackrel{N}{S}$ & $\stackrel{N}{D}$ & $\begin{array}{l}0 \\
\mathbb{1}\end{array}$ & 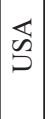 & 鼠 & & 1 & 脪 & 志 & $\begin{array}{l}\mathbb{N} \\
\text { D }\end{array}$ & $\begin{array}{l}\ll \\
\widetilde{\Omega} \\
.\end{array}$ & $\mid \begin{array}{l}\ll \\
\tilde{2} \\
\vdots\end{array}$ & 死 & $\begin{array}{l}\mathbb{\approx} \\
\stackrel{2}{D}\end{array}$ & $\begin{array}{l}\varangle \\
\widetilde{2} \\
2\end{array}$ & & \\
\hline 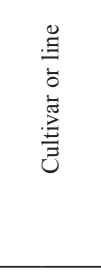 & 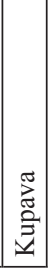 & 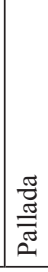 & 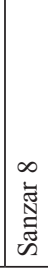 & \begin{tabular}{|l|}
8 \\
0 \\
0 \\
0 \\
0 \\
80 \\
3 \\
3 \\
5
\end{tabular} & 窇 & $\mid \begin{array}{c}\overline{0} \\
\overline{0} \\
\tilde{z} \\
\Sigma \\
\end{array}$ & $\left|\begin{array}{c}2 \\
\hat{0} \\
\tilde{z} \\
\Sigma\end{array}\right|$ & 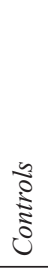 & \begin{tabular}{|l|}
8 \\
0 \\
0 \\
0 \\
$\vdots$ \\
$\Sigma$ \\
\end{tabular} & 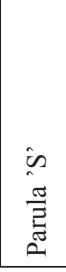 & $\begin{array}{l}\bar{\xi} \\
\bar{z}\end{array}$ & $\begin{array}{l}a \\
\dot{J} \\
B \\
\bar{z}\end{array}$ & 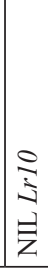 & 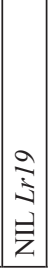 & 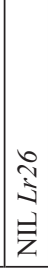 & 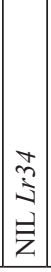 & $\begin{array}{c}\hat{n} \\
\vdots \\
\vdots \\
\vdots \\
z\end{array}$ & 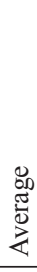 & $\stackrel{1}{\circ}$ \\
\hline
\end{tabular}


cantly lower $(\mathrm{P}=0.05)$ than the entries that did not have markers for these genes (average ACI of this group was 19.0) (Table 3). For the two genotypes with Lr68 including the control Parula a similar significant difference was observed, as their average ACI (4.7) was significantly lower than lines that did not carry the $\operatorname{Lr} 19, \operatorname{Lr} 37$ or $\operatorname{Lr} 68$ genes. For the $1^{\text {st }}$ observation data the differences were not statistically significant. In contrast, the group of six cultivars containing Lr34 gene showed a significantly lower average ACI value (2.0) for the first observation than cultivars that did not carry this gene (cultivars carrying the effective $L r 19, \operatorname{Lr} 37$ or $\operatorname{Lr} 68$ genes were excluded from this comparison), whereas the data of $2^{\text {nd }}$ observation showed no significant difference at $\mathrm{P}=0.05$. For $\operatorname{Lr} 19$ the statistical test could not be made as there was only one cultivar with this gene. For $L r 1$ and $L r 26$ genes none of these differences were significant.

The most susceptible Thatcher NILs $\operatorname{Lr} 1$ and $\operatorname{Lr} 26$ showed 29.3 and 32.0 ACI values (Table 2, $2^{\text {nd }}$ scoring), respectively, while NILs $\operatorname{Lr} 19$ and $\operatorname{Lr} 37$ had significantly lower infection (14.7 and 16.0 ACI values, respectively). Interestingly, NIL Lr10 showed similarly low infection severity (14.7 ACI), although its first scoring value did not differ significantly from that of the most susceptible NILs. It was also surprising that NIL Lr34 did not show any advantage in resistance at both scoring times as compared to the other NILs investigated.

Determining the effect of $\operatorname{Lr} 10$ was not easy because of the three cultivars carrying $L r 10$, cv. Yegemen also had $L r 68$, which provided an effective resistance. The two other cultivars, Dinara and Adyr, with $\operatorname{Lr} 10$ gene showed an average level of infection indicating that the gene did not condition effective resistance.

Cultivars Adyr $(L r 1+L r 10+L r 26)$ and Karasay $(L r 1+L r 26+L r 34)$ had the highest number of resistance genes, although $L r 1$ and $L r 26$ were not effective against the leaf rust pathotypes present in the field nurseries.

Table 3. The group averages of ACI values of wheat cultivars sorted by the presence and absence of $L r$ genes under artificial infection conditions (2012-2014, Almalybak, Almaty region, Kazakhstan)

\begin{tabular}{|c|c|c|c|c|c|c|}
\hline \multirow[b]{2}{*}{ Gene } & \multirow{2}{*}{$\begin{array}{l}\text { Leaf rust } \\
\text { score }\end{array}$} & \multicolumn{2}{|c|}{ Without gene } & \multicolumn{2}{|c|}{ With gene } & \multirow{2}{*}{$\begin{array}{c}\text { Significant diff. } \\
\text { of means** }(\mathrm{P}=5 \%)\end{array}$} \\
\hline & & $\begin{array}{c}\text { No. of } \\
\text { observation data* }\end{array}$ & $\begin{array}{c}\text { ACI } \\
\text { Average* }\end{array}$ & $\begin{array}{c}\text { No. of } \\
\text { observation data }\end{array}$ & $\begin{array}{c}\text { ACI } \\
\text { average }\end{array}$ & \\
\hline \multirow[t]{2}{*}{ Lr1 } & $1 \mathrm{st}$ & 8 & 7.0 & 17 & 5.5 & NS \\
\hline & $2 \mathrm{nd}$ & 8 & 21.8 & 17 & 17.8 & NS \\
\hline \multirow[t]{2}{*}{$\operatorname{Lr} 26$} & $1 \mathrm{st}$ & 19 & 5.9 & 5 & 6.3 & NS \\
\hline & $2 \mathrm{nd}$ & 19 & 19.5 & 5 & 17.7 & NS \\
\hline \multirow[t]{2}{*}{ Lr34 } & $1 \mathrm{st}$ & 19 & 7.2 & 6 & 2.0 & $\mathrm{~S}$ \\
\hline & $2 \mathrm{nd}$ & 19 & 20.0 & 6 & 15.9 & NS \\
\hline \multirow[t]{2}{*}{ Lr37 } & $1 \mathrm{st}$ & 25 & 6.0 & 3 & 2.2 & NS \\
\hline & 2nd & 25 & 19.0 & 3 & 5.3 & $\mathrm{~S}$ \\
\hline \multirow[t]{2}{*}{$\operatorname{Lr} 68$} & $1 \mathrm{st}$ & 25 & 6.0 & 2 & 2.3 & NS \\
\hline & 2 nd & 25 & 19.0 & 2 & 4.7 & $\mathrm{~S}$ \\
\hline
\end{tabular}

* Data of cultivars with $\operatorname{Lr} 19, \operatorname{Lr} 37$ and $\operatorname{Lr} 68$ were excluded from analysis.

**NS = not significant; $\mathrm{S}=$ significant at $5 \%$ level of probability. 


\section{Discussion}

Among a collection of 30 winter wheat cultivars produced in Kazakhstan three leaf rust resistance genes ( $\mathrm{Lr} 1, \mathrm{Lr} 26$ and $\mathrm{Lr} 34$ ) were demonstrated to occur at high frequency. Of these leaf rust resistance genes, only Lr34 showed evidence of providing adequate protection (only at the $1^{\text {st }}$ scoring time) in the cultivars investigated. In contrast $\operatorname{Lr} 9, \operatorname{Lr} 19, \operatorname{Lr} 37$ and $\operatorname{Lr} 68$ were at low frequency and provided resistance in the field, but their occurrence was low or not present in these genotypes.

According to Pathan and Park (2006) and Gultyaeva (2012), the most frequent leaf rust resistance genes in European and Russian wheat cultivars were: Lr1, Lr10, Lr26, and $L r 37$. The results of this study among Kazakh wheats also showed high frequency of $L r 1$ (57\%), although the $\operatorname{Lr} 1$ NIL was susceptible in the field indicating that this gene is ineffective in Kazakhstan. Although the broad effectiveness of Lrl is questionable, there is some support for its use in breeding when combined with other genes (McIntosh et al. 1995).

The Lr10 resistance gene, which was one of the most widespread genes reported in Russian cultivars (Gultyaeva et al. 2012), has been suggested to be useful when combined with other resistance genes (McIntosh et al. 1995). In this study 3 genotypes with $\mathrm{Lr} 10$ gene were identified. With the exception of cv. Yegmen, which carried the highly effective Lr68, these cultivars showed moderate resistance to the Kazakh population of leaf rust in field assessments. The wide distribution of cultivars with $\mathrm{Lr} 10$ has been historically associated with the appearance of virulent isolates and loss of its effectiveness in many regions of the world (McIntosh et al. 1995), and so the sources of Lr10 identified in this study can be considered for use as parents in breeding for combination with other effective $L r$ genes in Kazakhstan.

Lr19 is still effective worldwide, but it has been used commercially only on a limited scale due to associated flour quality issues. There is some evidence for the loss of effectiveness of Lr19 in the Volgo-Vyatsky region of Russia (Viuchkov 1998). However in Kazakhstan this gene remains effective (Rsaliev 2009; Koishybayev et al. 2010) and in the present study cv. Pallada (from Russia) carrying Lr19 was highly effective in the field nursery.

The leaf rust resistance gene $\operatorname{Lr} 26$ is located on the 1BL.1RS translocation and linked to $\mathrm{Yr} 9$ and $\mathrm{Sr} 31$ genes for resistance to yellow and stem rusts, respectively. It is one of the most predominant genes in wheat cultivars in many countries, including Russian and Kazakh wheat cultivars (Rsaliev 2009). Virulence for Lr26 has been widely reported (Pretorius 1988; Kosman et al. 2004). In our present study this gene also failed to show effective protection against leaf rust and cannot be recommended for use to improve leaf rust resistance. However, the 1BL.1RS translocation carrying Lr26 still remains important for breeding due to linkage with genes that provide adaptation and protection against other biotic and abiotic stresses (Moreno-Selvia et al. 1995; Singh et al. 1998).

In this study, the well-documented slow rusting character of Lr34 was supported. As this gene is also known to be linked to a yellow rust $(\mathrm{Yr} 18)$ and a powdery mildew $(\mathrm{Pm} 38)$ resistance gene, the use of it is recommended in the Central Asian region. The ineffective- 
ness of Lr34 in the tester line might come from a genetic interaction of Lr34 with other genes carried by cv. Thatcher the back cross parent of NILs. Whatever is the exact explanation of ineffectiveness of Lr34 in Thatcher background, the slow-rusting character of Lr34 in wheat cultivars produced in Kazakhstan was apparent.

Lr37 was a highly effective gene worldwide when initially deployed (McIntosh et al. 1995). In the Czech Republic, cultivars possessing Lr37 (Apache, Bill, Caphorn, Clarus, Clever) are among the most resistant (Bartoš et al. 2004). Although virulence for $\operatorname{Lr} 37$ has occurred in Europe and Australia, this gene is still recommended for breeding in many countries, including Russia and Kazakhstan (Gultyaeva et al. 2012; Koishybayev et al. 2010). The yellow rust resistance gene $\operatorname{Yr} 17$ linked to $L r 37$ is still effective against yellow rust in some regions and may explain the popularity of this gene complex in certain breeding programs. In our study the Lr37 NIL showed moderate resistance in the field, whereas three wheat entries (Krasnovodopadskaya 210, L-1090 and Madsen) carrying this gene were highly resistant, suggesting additional unknown genes were also contributing to the response.

The origin of Lr68 is likely to be the Brazilian wheat cultivar Frontana, which appears in the pedigree of Parula and various other CIMMYT wheats (Herrera-Foessel et al. 2012). The additive effects of Lr68 in combination with slow rusting genes Lr34 and Lr46 were confirmed at multilocation experiments (Lillemo et al. 2011). In our study Lr68 was found only in cultivar Yegemen and in the positive control cultivar Parula. Both of these genotypes showed very good resistance to leaf rust in Kazakhstan, and so the use of this gene is recommended in regional resistance breeding.

This study showed that molecular markers are a convenient and efficient approach to identify effective leaf rust resistance genes in cultivars and lines, and particularly so where a well-characterized pathogen collection is not available for multi-pathotype assessments. Marker-assisted selection can be efficiently applied to develop wheat cultivars with effective gene combinations that would directly assist in developing durable resistance in Kazakhstan. The key will be identifying parental breeding material with diverse and effective leaf rust resistance, and continued international collaboration with partners such as CIMMYT and ICARDA will be of great value in giving access to materials for evaluation.

\section{Acknowledgements}

The authors acknowledge to researchers of the Laboratory of Genetics and Breeding of the Institute of Plant Biology and Biotechnology, Department of the Gene Pool of the Kazakh Research Institute of Agriculture and Plant Growing for contributions in accessing the field data and in promoting research. Special thanks to Dr. J. A. Kolmer (USDA-ARS, St Paul, MN, USA) for providing us the Lr-NILs of cv. Thatcher. The authors gratefully thank to Dr. Colin Wellings (University of Sydney) for the accurate correction of manusscript. 


\section{References}

Bartoš, P., Ovesna, J., Hanzalova, A., Chrpova, J., Dumalasova, V., Skorpik, M., Sip, V. 2004. Presence of a translocation from Aegilops ventricosa in wheat cultivars registered in the Czech Republic. Czech J. Genet. Plant Breed. 40:31-35.

Feuillet, C., Messmer, M., Schachermayr, G., Keller, B. 1995. Genetic and physical characterization of the $L r 1$ leaf rust resistance locus in wheat (Triticum aestivum L.). Mol. Gen. Genet. 248:553-562.

Gultyaeva, E.I. 2012. Methods for the identification of genes for resistance of wheat to leaf rust using DNA markers and characteristics of effective $\mathrm{Lr}$ genes. Russian Academy of Agricultural Sciences: VIZR. SaintPetersburg, Russia. 72 p.

Helguera, M., Khan, I.A., Kolmer, J., Lijavetzky, D., Zhong-qi, L., Dubcovsky, J. 2003. PCR assays for the Lr37-Yr17-Sr38 cluster of rust resistance genes and their use to develop isogenic hard red spring wheat lines. Crop Sci. 43:1839-1847.

Herrera-Foessel, S.A., Singh, R.P., Huerta-Espino, J., Rosewarne, G.M., Periyannan, S.K., Viccar, L., CalvoSalazar, V., Lan, C., Lagudah, E.S. 2012. Lr68: a new gene conferring slow rusting resistance to leaf rust in wheat. Theor. Appl. Genet. 124:1475-1486.

Koishybayev, M.K., Zhanarbekova, A.B., Kokhmetova, A.V., Rsaliev, Sh.S. 2010. Genetic study of wheat resistance to leaf rust. Bulletin of National Academy of Sciences of Kazakhstan 6:10-15.

Kokhmetova, A., Sapakhova, Z., Madenova, A., Yessenbekova, G. 2014. Identification of carriers of yellow Yr5, Yr10, Yr15 and leaf Lr26, Lr34 rust resistance genes under molecular screening of wheat entries. Biotechnology. Theory and Practice 1:71-78.

Kosman, E., Pardes, E., Anikster, Y., Manisterski, J., Yehuda, P.B., Szabo, L.J., Sharon, A. 2004. Genetic variation and virulence on Lr26 in Puccinia triticina. Phytopathol. 94:632-640.

Lagudah, E.S., McFadden, H., Singh, R.P., Huerta-Espino, J., Bariana, H.S., Spielmeyer, W. 2006. Molecular genetic characterization of the $L r 34 / Y r 18$ slow rusting resistance gene region in wheat. Theor. Appl. Genet. 114:21-30.

Lillemo, M., Singh, R.P., William, M., Herrera-Foessel, S.A., Huerta Espino, J., German, S., Campos, P., Chaves, M., Madriaga, R., Xia, X.C., Liang, S.S., Liu, D., Li, Z.F., Lagudah, E.S. 2011. Multiple rust resistance and gene additivity in wheat: Lessons from multi-location case studies in the cultivars Parula and Saar. BGRI Technical Workshop. St. Paul, Minnesota, USA. pp. 111-120.

McIntosh, R.A., Wellings, C.R., Park, R.F. 1995. Wheat Rusts: An Atlas of Resistance Genes. CSIRO. Sydney, Australia. pp. 234-237.

McIntosh, R.A., Dubcovsky, J., Rogers, J., Morris, C., Appels, R., Xia, X. 2010. Catalogue of gene symbols for wheat: 2010 supplement. http: www.shigen.nig.ac.jp/wheat/komugi/genes/macgene 2010

Moreno-Sevilla, B., Baenziger, P.S., Peterson C.J., Graybosch, R.A., McVey, D.V. 1995. The 1BL/1RS translocation: Agronomic performance of $\mathrm{F}_{3}$-derived lines from a winter wheat cross. Crop Sci. 35:1051-1055.

Pathan, A.K., Park, R.F. 2006. Evaluation of seedling and adult plant resistance to leaf rust in European wheat cultivars. Euphytica 149:327-342.

Peterson, R.F., Campbell, A.B., Hannah, A.E. 1948. A diagrammatic scale for estimating rust intensity of leaves and stem of cereals. Can. J. Res. Sect. C 26:496-500.

Pretorius, Z.A. 1988. First report of virulence to wheat leaf rust resistance gene Lr26 in South Africa. Plant Dis. 72:175.

Prins, R., Groenewald, J.Z., Marais, G.F., Snape, J.W., Koebner, R.M.D. 2001. AFLP and STS tagging of Lr19, a gene conferring resistance to leaf rust in wheat. Theor. Appl. Genet. 103:618-624.

Riede, C.R., Anderson, J.A. 1996. Linkage of RFLP markers to an aluminum tolerance gene in wheat. Crop Sci. 36:905-909.

Roelfs, A.P., Singh, R.P., Saari, E.E. 1992. Rust diseases of wheat: Concepts and methods of disease management. CIMMYT. Mexico, D.F., Mexico. 81 p.

Rsaliev, A.S. 2009. Resistance of spring durum wheat varieties (Triticum durum Desf) to rust diseases. Ph.D thesis of a dissertation for the Degree of Candidate of Agricultural Sciences on specialty 06.01.05 Plant Breeding and Seed Growing. CopyLand. Almalybak, Kazakhstan. 25 p. 
Rsaliev, Sh.S., Sedlovskii, A.I., Rsaliev, A.S., Tileubaeva, Zh.S., Tyupina, L.N., Yessenbekova, G.T., Atishova, M.N., Agabayeva, A.Ch. 2011. Catalogue of wheat cultivars and samples with resistance genes to leaf rust. IP Volkova. Almaty, Kazakhstan. 100 p.

Schachermayr, G., Siedler, H., Gale, M.D., Winzeler, H., Winzeler, M., Keller, B. 1994. Identification and localization of molecular markers linked to the $\operatorname{Lr} 9$ leaf rust resistance gene of wheat. Theor. Appl. Genet. 88:110-115.

Schachermayr, G., Feuillet, C., Keller, B. 1997. Molecular markers for the detection of the wheat leaf rust resistance gene $\mathrm{Lr} 10$ in diverse genetic backgrounds. Mol. Breeding 3:65-74.

Singh, R.P., Huerta-Espino, J., Rajaram, S., Crossa, J. 1998. Agronomic effects from chromosome translocations 7DL.7 Ag and 1BL.1RS in spring wheat. Crop Sci. 38:27-33.

Stubbs, R.W., Prescott, E.E., Saari, E.E., Dubin, H.J. 1986. Cereal disease methodology manual. CIMMYT. Mexico D.F., Mexico. 46 p.

Viuchkov, A.A. 1998. Breeding of spring bread and durum wheat in Middle Povoloje. Thesis of dissertation for the degree of Doctor Agricultural Sciences: 06.01.05. Bezenchuk, Russia. 66 p.

Weng, Y., Azhaguvel, P., Devkota, R.N., Rudd, J.C. 2007. PCR-based markers for detection of different sources of 1AL.1RS and 1BL.1RS wheat-rye translocation in wheat background. Plant Breed. 126:482486. 